Causes of reticence: Engendering willingness to speak in language classrooms

Riasati, Mohammad Javad $\$

Department of Foreign Languages, Shiraz Branch, Islamic Azad University, Shiraz, Iran (Mjriasati2002@yahoo.com)

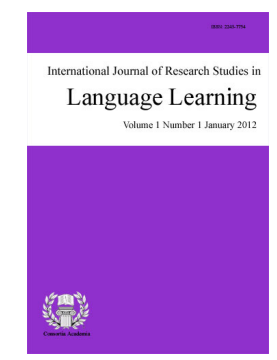

ISSN: $2243-7754$ Online ISSN: 2243-7762 OPEN ACCESS
Received: 20 March 2013

Available Online: 23 October 2013
Revised: 22 August 2013 DOI: $10.5861 /$ ijrsll.2013.410
Accepted: 23 August 2013

\begin{abstract}
A common problem faced by many language teachers, both in EFL and ESL settings, is the students' unwillingness to speak and participate in classroom activities. The present study delves into this issue by reviewing studies concerning this issue to figure out how different researchers have attempted to identify the causes of students' reticence and lack of participation. The study aims to come up with some practical techniques and strategies teachers can employ in order to discover causes of reticence among language learners and thus make them more willing to speak in language classrooms.
\end{abstract}

Keywords: reticence; willingness to speak; participation; language learners; language learning 


\section{Causes of reticence: Engendering willingness to speak in language classrooms}

\section{Introduction}

In the past, the goal of language learning was for the learners to master the structures of the language. However, in this age of communication, modern language pedagogy attaches great importance to communication and training individuals who will eventually be able to use their language for communicative purposes. In fact, the goal of modern language teaching and learning is to encourage learners to use the language for meaningful and effective communication, not only inside, but also outside the classroom.

Whether in second language learning situations or foreign language settings, second/foreign language learners have often been observed to be reluctant to take part in class activities. Such reluctance and passivity will make them lose their motivation in learning the language. By reviewing past studies conducted in this area, the present study attempts to identify the causes of such reluctance, with the goal to make foreign language learning and teaching more effective.

\section{Research on Causes of Reticence}

Different researchers have employed different ways of identifying students' reasons of reticence. Using interviews, observations, and journals written by second/foreign language learners, researchers have managed to discover why some language learners choose to remain silent in language classrooms. Dwyer and Heller-Murphy (1996), for example, interviewed six Japanese students at the University of Edinburgh to identify sources of reticence among language learners. It was found that students were reticent due to several reasons including fear of public failure, fear of making mistakes, low English proficiency, lack of self-confidence, and lack of familiarity with rules and norms of English conversation.

Similar studies were also conducted in EFL settings. Flowerdew and Millar (2000) interviewed fifteen lecturers in a university in Hong Kong. It was found that students were passive and reticent in language classrooms as a result of such reasons as fear of losing face, their inability to understand concepts, the passive learning styles they were accustomed to, lack of preparation before coming to class, and their perceived linguistic ability.

Using journals, observations and interviews, Liu (2005) investigated Chinese EFL learners' reticence. It was revealed that very few students were willing to speak individually in class, while many more were expressed their willingness to participate in pair and group activities. A number of reasons were identified as contributing to the learners' reticence. Reasons include low English proficiency, personality, fear of speaking, difficulty of the task, fear of making mistakes, unfamiliarity with the interlocutor and the environment, teacher' teaching style, and lack of familiarity with the task.

Liu and Jackson (2009) investigate students' reticence in oral English lessons at the tertiary level. The researchers used surveys observations, reflective journals, and interviews as data collection techniques. It was found that students who benefited from a higher proficiency level were more willing to speak in class. Moreover, giving a lecture was found to be the least favorite activity, while pair work was rated as a popular activity. Students" willingness to take part in class activities was found to increase as a result of their exposure to spoken language and familiarity with the environment.

Similar findings were achieved by $\mathrm{Li}$ and Liu (2011) who examined the issue of reticence and anxiety in Chinese setting. It was found that many learners were unwilling to take risk with the language and thus preferred to remain silent during class discussion. A range of factors were identified as leading to reticence. These factors include lack of self-confidence, lack of preparation, fear of making mistakes, lack of knowledge or interest in the 
discussion, and students' personality.

Donald (2010) investigated the issue of reticence from the perspective of teachers and students. Results demonstrated that fear of making mistakes, and error correction and how it was done played significant roles in determining students' reticence. Group work proved effective in reducing reticence among the participants.

In a recent qualitative study, Riasati (2012) explored Iranian EFL learners' perception of factors influencing their willingness to speak in language classrooms. The interview results showed a range of factors including task type, topic of discussion, role of interlocutor, role of teacher, class atmosphere, learners' self-perceived speaking ability, and their personality. It was also found that students' fear of evaluation and fear of correctness of speech reduced their willingness to speak in class.

\section{Solutions to Students' Reticence}

Clearly, reticence exerts detrimental influence on the effectiveness of foreign language learning process. As such, researchers working in the field have suggested some techniques and strategies as solutions to the problem. What follows is brief overview of such solutions.

\subsection{Following Communicative Language Teaching Method}

In the history of language teaching methodologies, a great variety of teaching methods and techniques have evolved, existed for some time and then disappeared and were replaced with a seemingly more effective teaching method. However, the one that is in the spotlight in the present century is Communicative Language Teaching (CLT). The goal of communicative language teaching is to encourage learners to engage in communication as frequently and efficiently as possible in the language classroom environment, hoping that such engagement will help them initiate communication in out-of-classroom settings (Richards, 2006). The goal of CLT is to train language learners who will be able to use their language effectively in communicative situations. It is the need to communicate that can remove reticence in class and fosters' classroom participation. CLT could thus be seen as the most effective way of encouraging inactive learners to participate in class activities.

\subsection{Role of Teacher}

It is proved that the vital role the teacher plays in making learners willing or unwilling to speak cannot be neglected. If a teacher pays equal attention to all members of the class, encourages everybody to take part in classroom debates and activities, and gives enough time to students to participate, he or she can considerably enhance the students' willingness to speak. On the contrary, the teachers who are dictators, tend to dominate a discussion and take the floor, impose their viewpoints to the learners and do not give much freedom to them to voice their opinions are indeed doomed to failure. Lisa (2006), too, contends that a student-centered approach is much more effective than a teacher-oriented one while enhancing learners' willingness to talk. As such, a teacher's attitude and teaching style can dramatically influence the learners' willingness to participate.

Another important role of the teacher in this regard is creating a situation in which everybody feels relaxed to air out what they have in mind. Making such a stress-free environment can considerably contribute to an increase in the learners' degree of willingness to speak. Sun (2008) who highlights teachers' influential role in the process of learning the language. The researcher argues that all the behavior a teacher displays in class have an impact on the students' motivation to participate. The way a teacher conducts a lesson and the way he or she interacts with the students determine the learners' willingness to participate. If a teacher, for example, repeatedly pinpoints the learners' mistakes and humiliates them in front of others, such a behavior will have a negative impact on the learners. Teachers, therefore, are responsible for creating opportunities for learners to participate. Without creating such opportunities, learners will remain reticent as their wish to communicate is not attended to (Lee \& Ng, 2010). In line with this, the participants in Liu's (2005) study complain that they are not given enough time by their teacher to speak in class, and that the teaching style of the teacher is a major factor in 
forming their willingness to speak behavior. More recent research (e.g. Sun, 2008; Cao, 2009; Tong, 2010; Zeng, 2010), too, confirm the findings of the present study and acknowledge the important role of teacher in facilitating or inhibiting learners' participation.

\subsection{Classroom Atmosphere}

Classroom atmosphere can either facilitate or hinder learners' participation in class activities. They tend to speak more in an environment which is friendly enough so that they feel secure and relaxed. However, the responsibility of creating such an atmosphere lies primarily with the teacher who needs to be very deliberate in making choices that can make a classroom an inviting place to learn or conversely a threatening environment for the learners. It goes without saying that a positive, stress-free learning environment can make a classroom fun for the learners and thus a more effective and encouraging setting, which can lead to better educational achievements. Indeed, in such a learning environment students feel free to speak up, ask and answer questions, challenge the teacher and other classmates, and have a more active participation in class discussions. This is consistent with Zeng (2010) who contends that learners' degree of participation increases as a result of the relaxing environment in which they learn and the degree of familiarity with it. One reason could be the fact that in a relaxing environment, learners get to know and trust each other better. This would contribute to more participation. Moreover, in such an environment, learners feel secure enough to express themselves and are not afraid of making mistakes and then being ridiculed. They can make certain that even if they make a mistake or run into a difficulty, others will respond in a friendly and encouraging manner. Another advantage of putting learners in a relaxing environment is that "similarities are appreciated and differences are tolerated" (Zeng, 2010, p. 197).

Nagy and Nikolov (2007) propose that a student-friendly and supportive environment be created so that learners would be more willing to talk in class. In a stress-free supporting environment, learners can build a better rapport not only with each other but also with the teacher, which will in turn boost the learning process to a considerable extent. Liu (2007), too, stresses the importance of creating a stress-free supportive environment for the learners with the goal to make them eager to speak. Other research (e.g. Sun, 2008; Tsiplakides \& Keramida, 2009; Cao, 2009) have also reported the importance of creating a learning environment that leads to more participation on behalf of learners.

The findings of the study also suggest that creating a relaxing environment leads to a higher degree of willingness to speak on the learners' part. One way to achieve this is by creating intimacy in class. It is recommended that teachers call the learners by their first names, as this will remove barriers between them. Another way is to choose topics that most of the students share an interest in. The more students know each other's interests, the more they will have in common and the more comfortable they are likely to be. Another technique for teachers is to show a personal interest in the students' lives (Cutrone, 2009). This is referred to as "the removal of teacher's mask" (Stevick, 1980). Some of the strategies Stevick suggests are creating a friendly relationship with the students, mingling with them in their small talks, and speaking to them individually from time to time. Another factor that may make the classroom atmosphere anxiety-provoking is the existence of evaluation environment in the classroom.

Moreover, teachers need to create a supportive environment in language classes, which will dramatically influence the learning process. A supportive learning environment makes learners more motivated, confident, and less anxious in speaking English, and gives them a higher perception of their abilities (Lisa, 2006). Learners need to be taught to be supportive of each other and help each other to improve. Teachers need to help students to become acquainted with each other and feel that they are all members of a group. Creating a sense of cooperation rather than competition among students puts them at ease to use the language (Zou, 2004). Liu (2007) suggests teachers to be friendly rather than strict, as teacher's being strict discourages learners from speaking. 


\subsection{Role of Topic}

The topic of discussion plays a vital role in making learners willing or unwilling to speak. To learners, topic familiarity, topic interest, and topic preparation are the essential features of a certain topic. Moreover, learners tend to discuss a topic that is controversial as well as a topic they feel they are more comfortable with (Riasati, 2012). It goes without saying that the type of topic under discussion influences the ease of language use to a great extent. Having enough knowledge about a certain topic and being familiar with the register enhance one's linguistic self-confidence, while lack of knowledge about a topic and its appropriate register result in one's avoiding communication (MacIntyre, Clément, Dörnyei \& Noels 1998). As Kang (2005) contends, some particular topics may bring about greater "responsibility" to involve; that is, one feels the need to discuss a topic because it is intrinsically and instrumentally interesting to him or her. Finally, one's lack of knowledge, interest, and preparation for a certain topic can greatly influence one's perceived competence since one feels he or she has nothing to contribute and hence prefers to remain silent. Such affective constraints can considerably reduce one's degree of willingness to speak.

The respondents' concern about the topic they are discussing and its fundamental role in making them active or passive in discussions was another finding of the study. This implies that to generate willingness to speak among individuals, they need to discuss topics they are interested in, familiar with, and for which they are prepared to talk. This is indicative that teachers should provide students with such topics in order to encourage them to speak. To do this, teachers need to know their students' areas of interest. Kang (2005) suggests brainstorming, taking a survey, and getting learners to propose discussion topics as the techniques teachers can adopt to identify the topics learners prefer to discuss. Another thing teachers can do is to get the learners to interview each other in order to know each other better and discover one another's area of interest. With this in mind, they can group them in more homogenous groups in order to increase their participation and involvement.

\subsection{Reducing Learners'Anxiety}

The findings of the study also showed that there is a negative correlation between willingness to speak and language learning anxiety. Moreover, anxiety was proved to be the best predictor of willingness to speak. As a result, if the aim of language education is to create willingness to speak among language learners, language learning anxiety needs to be removed or at least minimized. To achieve this goal, language practitioners need to be aware that the existence of anxiety can have a debilitating effect on the learners' achievement and that the "tension and discomfort related to language learning call for the attention of the language teaching profession" (Horwitz, 2001, p.122). In an attempt to aid in its prevention, teachers need to identify the causes of anxiety in language classrooms and take measures to obliterate them to the extent possible.

Teachers also need to help learners cope with their anxiety. One useful technique is to run activities that are less stressful to learners (e.g. pair and group work) and gradually move towards activities that may cause more apprehension (e.g. giving a lecture in front of class). The interview respondents of the present study, too, acknowledged that they are more willing to speak in pairs and groups rather than individually. Moreover, in handling with reticence, teachers should not show annoyance at the learners' reticence, as this will only aggravate the situation and will cause more anxiety. If learners get to know the teacher is getting annoyed at their reticence, they feel insecure and apprehensive. Another strategy a teacher can employ to reduce anxiety and hence create a friendly environment is to use humor from time to time, as this will reduce the tension of the class to a great extent and will establish rapport with the learners (Christophel, 1990). In dealing with passive and reticent learners, it is also recommended that teachers give them more opportunity to speak in a positive, caring atmosphere. Having seen the concern and care of the teacher, the reticent students will be gradually more willing to speak (Liu \& Jackson, 2008).

As willingness to speak and language learning anxiety are shown to be correlated in the present study and given the fact that anxiety is proved to be the best predictor of willingness to speak, it is really necessary for 
language teachers to remove the students' anxiety so that they can have a more active participation in class. Teachers can tell learners that the way to achieve success on the journey of learning the language is paved through having active participation in class discussions. Being aware of this, learners will take conscious measures to be more active in classroom activities. Furthermore, teachers can hold private meeting with those language learners whom they feel are more anxious than others so that they can find the sources of anxiety specific to them (Riasati, 2011).

\subsection{Fear of Evaluation}

Students should feel that the teacher is not listening to them merely because of evaluating their language. One technique to achieve this is the way that teachers correct students' errors. In the researcher's experience, overt correction discourages learners from speaking and will create anxiety in classroom. Clearly, teachers need to take less obtrusive measures in error correction (Cutrone, 2009). In creating a secure environment, Kang (2005) suggests that teachers need to remove students' fear of making mistakes and losing face by listening to them attentively while smiling and then providing their feedback. In fact, fear of negative evaluation is a factor that causes anxiety while speaking, which will, in turn, discourage learners from speaking. Teacher' overcorrections can "draw students' attention away from communication and toward a focus on form and accuracy" (Gregersen, 2003, p. 31). Teachers should also make learners aware of the fact that nobody is perfect and that everybody makes mistakes, especially in learning something for the first time such as learning a foreign language. With this in mind, learners will not always be obsessed with the fear of making mistakes and losing face.

\subsection{Task Type}

Research indicates that learners are more willing to speak in pairs and groups rather than individually. One reason could the fact that they feel more comfortable speaking with their peers rather than their teacher, since their peers' English proficiency level is similar to theirs, so they can feel more comfortable speaking to somebody who knows almost as much as they know. Moreover, during such activities, they have the chance to exchange ideas and hence learn from each other. In their study, Riazi and Riasati (2007) found out that pair and group activities are preferred to speaking individually. Around 65 percent of the participants who were Iranian EFL learners learning English in language institutes preferred to practice their language in pairs and groups rather than on their own. Likewise, Cetinkaya (2005) showed that the individuals in his study preferred to speak in dyads or groups rather than speaking individually in front of a large group of people. Cao and Philp (2006), too, contend that running a pair- or group work in class gives individuals greater opportunity to speak than in the case of speaking individually. The participants in their study reported that they were more willing to speak in groups with a small number of participants, ideally three or four members, since they have the opportunity to help each other and learn from each other. As such, language teachers are advised to incorporate more pair- and group-work activities into their teaching syllabus.

\section{Conclusion}

Reticence is undoubtedly a serious and common problem in foreign language learning environments. In order to foster learners' participation in class activities and thus lessen their degree of reticence, teachers need to first identify the factors that may cause reticence and accordingly take measures to obliterate them to the extent possible. Therefore, this issue is worthy to be further explored in different contexts with the goal to make learners more willing to speak in class and ultimately improve the learning and teaching situation.

\section{References}

Cao, Y. (2009). Understanding the notion of interdependence and the dynamics of willingness to communicate. Unpublished doctoral dissertation. The University of Auckland, Auckland, New Zealand. 
Cao, Y., \& Philp, J. (2006). Interactional context and willingness to communicate: A comparison of behavior in whole class, group and dyadic interaction. System, 34, 480-493. http://dx.doi.org/10.1016/j.system.2006.05.002

Cetinkaya, Y. B. (2005). Turkish college students' willingness to communicate in English as a foreign language. Unpublished doctoral dissertation. Ohio State University.

Christophel, D. M. (1990). The relationships among teacher immediacy behavior, student motivation, and learning. Communication Journal, 39, 323-340.

Cutrone, P. (2009). Overcoming Japanese EFL learners' fear of speaking. Language Studies Working Papers, 1, $55-63$.

Donald, S. (2010). Learning how to speak: Reticence in the ESL classroom. ARECLS, 7, 41-58.

Dwyer, E., \& Heller-Murphy, A. (1996). Japanese learners in speaking classes.

Flowerdew, J., \& Miller, L. (2000). Chinese lecturers' perceptions, problems and strategies in lecturing in English to Chinese-speaking students. RELC, 31, 116-138. http://dx.doi.org/10.1177/003368820003100106

Gregersen, T. S. (2003). To err is human: A reminder to teachers of language-anxious students. Foreign Language Annals, 36(1), 25-32. http://dx.doi.org/10.1111/j.1944-9720.2003.tb01929.x

Horwitz, E. K. (2001). Language anxiety and achievement. Annual Review of Applied Linguistics, 21, 112-126. http://dx.doi.org/10.1017/S0267190501000071

Kang, S. J. (2005). Dynamic emergence of situational willingness to communicate in a second language. System, 33, 277-299. http://dx.doi.org/10.1016/j.system.2004.10.004

Lee, W., \& Ng, S. (2010). Reducing student reticence through teacher interaction strategy. ELT Journal, 64(3), 302-313. http://dx.doi.org/10.1093/elt/ccp080

Li, H., \& Liu, Y. (2011). A brief study of reticence in ESL class. Theory and Practice in Language Studies, 1(8), 961-965. http://dx.doi.org/10.4304/tpls.1.8.961-965

Lisa, L. (2006). The relationship among teachers'verbal and non-verbal immediacy behaviors and students' willingness to speak in English in central Taiwanese college classrooms. Unpublished doctoral dissertation, Oral Roberts University, Tulsa, Oklahoma.

Liu, M. (2007). Anxiety in oral English classrooms: A case study in China. Indonesian Journal of English Language Teaching, 3(1), 119-137.

Liu, M. H. (2005). Reticence in oral English language classrooms: A case study in China. TESL Reporter, 38(1), $1-16$.

Liu, M., \& Jackson, J. (2009). Reticence in Chinese EFL students at varied proficiency levels. TESL Canada Journal, 26(2), 65-81.

Liu, M., \& Jackson, J. (2008). An exploration of Chinese EFL learners' unwillingness to communicate and foreign language anxiety. Modern Language Journal, 92(1), 71-86. http://dx.doi.org/10.1111/j.1540-4781.2008.00687.x

MacIntyre, P. D., Clément, R., Dörnyei, Z., \& Noels, K. A. (1998). Conceptualizing willingness to communicate in a L2: A situational model of L2 confidence and affiliation. The Modern Language Journal, 82(4), 545-562. http://dx.doi.org/10.1111/j.1540-4781.1998.tb05543.x

Nagy, B., \& Nikolov, M. (2007). A qualitative inquiry into Hungarian English major's willingness to communicate in English: Classroom perspectives. In J. Horvath \& M. Nikolov (Eds.), UPRT: Empirical Studies In English Applied Linguistics (pp. 149-168). Pecs: Lingua Franca Csoport.

Richards, J. C. (2006). Communicative language teaching today. Cambridge: Cambridge University Press.

Riasati, M. J. (2012). EFL learners' perception of factors influencing willingness to speak English in language classrooms: A qualitative study. World Applied Sciences Journal, 17(10), 1287-1297.

Riasati, M. J. (2011). Language learning anxiety from EFL learners' perspectives. Middle East Journal of Scientific Research, 7(6), 907-914.

Riazi, A., \& Riasati, M. J. (2007). Language learning style preferences: A students case study of Shiraz EFL institutes. Asian EFL Journal, 1, 156-188.

Stevick, E. W. (1980). Teaching languages: A way and ways. Rowley, MA: Newbury House. 
Riasati, M. J.

Sun, Y, F. (2008). Motivation to speak: Perception and attitude of non-English major students in Taiwan. Unpublished doctoral dissertation. Indiana University.

Tsiplakides, I., \& Keramida, A. (2009). Helping students overcome foreign language speaking anxiety in the English classrooms: Theoretical issues and practical recommendations. International Education Studies, 2(4), 39-44.

Tong, J. (2010). Some observations of students' reticent and participatory behavior in Hong Kong English classrooms. Electronic Journal of Foreign Language Teaching, 7(2), 239-254.

Zeng, M. (2010). Chinese students' willingness to communicate in English in Canada. Unpublished doctoral dissertation, Ontario, Canada.

Zou, M. (2004). EFL learners' perception of in-class relationships and their voluntary responses. In Y. Gao (Ed.), The social psychology of English learning by Chinese college students (pp. 149-167). Beijing: Foreign Language Teaching and Research Press. 